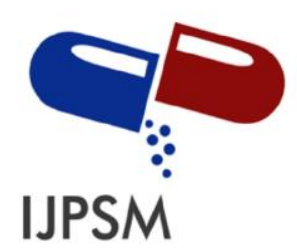

Meilinda Mustika et al, Int. Journal of Pharmaceutical Sciences and Medicine (IJPSM),

Vol.6 Issue. 3, March- 2021, pg. 14-20

ISSN: 2519-9889

Impact Factor: 3.426

\title{
Traditional Medicines Prescription and the Potential of Original Indonesian Herbs as Natural Immunomodulators
}

\author{
Meilinda Mustika $^{1}$; Harrizul Rivai ${ }^{2}$; Nailul Muna $^{1}{\text { Zarny } \text { Voenna }^{1} \text {; Harnisah }}^{1}$ \\ ${ }^{1}$ College of Pharmacy (STIFARM), Jl. Raya Siteba Kurao Pagang, Padang 25147, Indonesia \\ ${ }^{2}$ Faculty of Pharmacy, Andalas University, Limau Manih Campus, Padang 25163, Indonesia \\ "Email: harrizul@yahoo.co.id and harrizul@phar.unand.ac.id \\ DOI: 10.47760/ijpsm.2021.v06i03.002
}

\begin{abstract}
Traditional medicine is an ingredient or a recipe for components in the form of plant ingredients, animal ingredients, mineral substances, galenic preparations, or mixtures of these ingredients that have been used for treatment from generation to generation and can be applied by the prevailing norms in society. Traditional medicinal herbs can be an option for health maintenance, disease prevention, and health care and strengthening a person's immune system. With low prices and easy-tofind raw materials, traditional medicinal ingredients can be made and consumed at home. This review aims to provide information that native Indonesian herbs act as traditional medicines and also have potential as immunomodulators. The way to get this information is by searching through Google Scholar. The results show that many native Indonesian herbs act as natural immunomodulators. Therefore, it can be concluded that native Indonesian herbs can be developed into phytopharmaca as immunomodulators.
\end{abstract}

Keywords: Traditional medicinal ingredients, native Indonesian herbs, immunomodulators.

\section{Introduction}

Original Indonesian herbs are medicinal plants grown and cultivated in Indonesia and are used from generation to generation for health purposes [1]. Since ancient times, the Indonesian people have used traditional Indonesian medicinal ingredients to maintain health, prevent disease, and health care. Indonesian traditional medicinal ingredients can come from plants, animals, and minerals, but generally, those used come from plants. Traditional medicinal ingredients are one or more types of plants with other additives inert/neutral [2]. Immunity consists of 2 types: natural immunity (in native/native) and adaptive immunity (specific/acquired). Natural immunity is the body's first defense mechanism against infection. This immune response immediately kills microbes, stimulates adaptive immunity, and provides a signal essential for initiating B and T lymphocyte responses to specific antigens. Adaptive immunity develops more slowly than natural, requiring lymphocyte proliferation and differentiation to adapt to microbial invasion to produce a more efficient response when faced with the same microbial exposure. Immunomodulators are all drugs that can modify the immune response, stimulate natural and adaptive defense mechanisms, and can function as both immunosuppressants and immunostimulants. The body's defense system can be activated by administering immunomodulators to increase a person's immune response $[3,4]$.

Traditional medicinal herbs can be an option to strengthen a person's immune system. With low prices and easy-to-find raw materials, traditional medicinal ingredients can be made and consumed at home. The Ministry of Health of the Republic of Indonesia advises the public to take advantage of traditional herbs to maintain health, prevent disease, and maintain endurance [5]. Currently, immunomodulators made from local Indonesian plants are continuously being developed by experts. This review discusses traditional medicinal 


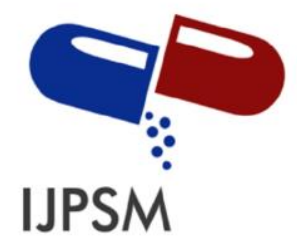

Meilinda Mustika et al, Int. Journal of Pharmaceutical Sciences and Medicine (IJPSM), Vol.6 Issue. 3, March- 2021, pg. 14-20

ISSN: 2519-9889

Impact Factor: 3.426

herbs and the potential of native Indonesian herbs as natural immunomodulators, including Cinnamomum burmanii (cinnamon), Curcuma longa (turmeric), Phyllanthus niruri (meniran), Zingiber officinale (ginger).

\section{Methods of data collection}

In compiling this review article, the technique used is to use literature studies by searching for sources or literature in primary data in official books and international journals in the last ten years (2011-2021). This review article's preliminary reference search is through trusted websites such as ResearchGate, Google Scholar, Elsevier, and other published and trustworthy journals.

\section{Indonesian traditional medicinal herbs}

Since ancient times, the Indonesian people have used traditional Indonesian medicinal ingredients to maintain health, prevent disease, and health care. Indonesian traditional medicinal ingredients can come from plants, animals, and minerals, but generally, those used come from plants. The following is a list of some traditional medicinal plants (Table 1), which contains the region's name, the part used, the traditional use, and herbs' preparation from several native Indonesian herbs [2].

Table 1: Some of the medicinal plants used in the manufacture of native Indonesian herbal recipes

\begin{tabular}{|c|c|c|c|c|c|}
\hline No. & Medicinal plants & Region name & The part used & Benefits & $\begin{array}{l}\text { How to make a } \\
\text { recipe }\end{array}$ \\
\hline 1 & $\begin{array}{l}\text { Cinnamomum } \\
\text { burmanii } \\
\text { (cinnamon) }\end{array}$ & $\begin{array}{l}\text { a) Sumatra: Holim, } \\
\text { modang siak-siak } \\
\text { (Batak), kanigar, madang } \\
\text { kulit manih (Minang); } \\
\text { b) Javanese: Huru } \\
\text { mentek, kiamis } \\
\text { (Sundanese), kanyengar } \\
\text { (Kangean); } \\
\text { c) Nusa Tenggara: } \\
\text { Kesingaar, cingar (Bali), } \\
\text { onte (Sasak), kaninggu } \\
\text { (Sumba), puundinga } \\
\text { (Flores). }\end{array}$ & Bark & $\begin{array}{l}\text { Menstrual } \\
\text { pain }\end{array}$ & $\begin{array}{l}\text { Boil } 2 \mathrm{~g} \text { of } \\
\text { ingredients with } \\
2 \text { cups of water } \\
\text { to } 1 \text { cup left, } \\
\text { cool, strain, and } \\
\text { divide into two } \\
\text { parts. } \\
\text { A total of } 2 \mathrm{~g} \text { of } \\
\text { the material is } \\
\text { crushed into a } \\
\text { powder, brewed } \\
\text { with } 1 \text { cup of } \\
\text { boiling water, let } \\
\text { stand, strain, } \\
\text { drink while } \\
\text { warm. }\end{array}$ \\
\hline 2 & $\begin{array}{l}\text { Curcuma domestica } \\
\text { (turmeric) }\end{array}$ & $\begin{array}{l}\text { a) Sumatra: kunyet } \\
\text { (Aceh), hunik (Batak); } \\
\text { b) Kalimantan: janar } \\
\text { (Banjar), cahang (Dayak } \\
\text { Panyabung); } \\
\text { c) Javanese: koneng, } \\
\text { temu kuning (Sundanese), } \\
\text { kunir (Javanese), konye, } \\
\text { temo koneng (Madura); } \\
\text { d) Nusa Tenggara: } \\
\text { Kunyik (Sasak); } \\
\text { Sulawesi: hamu (Sangir), } \\
\text { alawahu (Gorontalo); } \\
\text { Maluku: kumino, unin } \\
\text { (Ambon) }\end{array}$ & Rhizome & $\begin{array}{l}\text { Stiff pains } \\
\text { Back pain } \\
\text { Childbirth }\end{array}$ & $\begin{array}{l}\text { A total of } 20 \mathrm{~g} \text { of } \\
\text { ingredients is } \\
\text { brewed with } 1 \\
\text { cup of boiling } \\
\text { water; let stand, } \\
\text { strain, and drink } \\
\text { while warm. } \\
\text { As much as } 3 \mathrm{~g} \\
\text { of the material is } \\
\text { shredded, } \\
\text { attached to the } \\
\text { affected part, and } \\
\text { left to dry. } \\
\text { A total of } 1 \\
\text { handful of }\end{array}$ \\
\hline
\end{tabular}




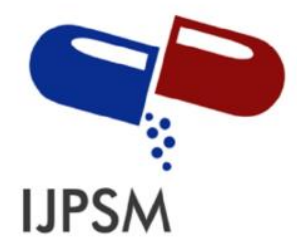

Meilinda Mustika et al, Int. Journal of Pharmaceutical Sciences and Medicine (IJPSM), Vol.6 Issue. 3, March- 2021, pg. 14-20

ISSN: 2519-9889

Impact Factor: 3.426

\begin{tabular}{|c|c|c|c|c|c|}
\hline & & & & & $\begin{array}{l}\text { mashed } \\
\text { rhizomes, boil in } \\
3 \text { cups of water } \\
\text { to become } 1 \text { cup, } \\
\text { cool, strain, drink } \\
\text { by adding lime } \\
\text { juice, honey, or } \\
\text { brown sugar to } \\
\text { taste, drink while } \\
\text { warm. }\end{array}$ \\
\hline 3 & $\begin{array}{l}\text { Phyllanthus niruri } \\
\text { (meniran) }\end{array}$ & $\begin{array}{l}\text { a) Sumatra: sidukuang } \\
\text { anak (Minang); } \\
\text { b) Javanese: meniran } \\
\text { green, meneniran } \\
\text { (Sundanese), meniran } \\
\text { (Javanese); } \\
\text { c) Ternate: gosau ma } \\
\text { dungi. }\end{array}$ & Herba & Mumps & $\begin{array}{l}\text { A total of } 10 \mathrm{~g} \text { of } \\
\text { ingredients are } \\
\text { boiled in } 2 \text { cups } \\
\text { of water to } 1 \text { cup, } \\
\text { cool, filter, and } \\
\text { drink all at once }\end{array}$ \\
\hline$\overline{4}$ & $\begin{array}{l}\text { Zingiber officinale } \\
\text { Rosc. (ginger) }\end{array}$ & $\begin{array}{l}\text { a) Sumatra: halia (Aceh), } \\
\text { sipodeh (Minangkabau), } \\
\text { jahi (Lampung); } \\
\text { b) Javanese: jae } \\
\text { (Javanese), jhai } \\
\text { (Madura); } \\
\text { c) Borneo: lai (Dayak); } \\
\text { d) Nusa Tenggara: jae } \\
\text { (Bali), reja (Bima); } \\
\text { e) Sulawesi: melito } \\
\text { (Gorontalo), song } \\
\text { (Bugis); } \\
\text { f) Maluku: sehi (Ambon), } \\
\text { siwei (Buru), geraka } \\
\text { (Ternate), gora (Tidore); } \\
\text { g) Papua: lali (Kalana } \\
\text { fat), manman (Kapaur) }\end{array}$ & Rhizome & $\begin{array}{l}\text { Back pain } \\
\text { Colds } \\
\text { Antinausea - } \\
\text { vomiting }\end{array}$ & $\begin{array}{l}\text { The ingredients } \\
\text { are shredded and } \\
\text { mixed with } \\
\text { tamarind; apply } \\
\text { on the part that } \\
\text { hurts. } \\
\text { The ingredients } \\
\text { are burned until } \\
\text { fragrant, crushed; } \\
\text { pour } 1 \text { cup of } \\
\text { boiling water, let } \\
\text { stand, and } \\
\text { enough palm } \\
\text { sugar and drink } \\
\text { while warm. } \\
\text { The ingredients } \\
\text { are refined; pour } \\
\text { them with boiling } \\
\text { water; you can } \\
\text { add honey or } \\
\text { brown sugar } \\
\text { according to your } \\
\text { taste, drink while } \\
\text { warm. }\end{array}$ \\
\hline
\end{tabular}

\section{Natural immunomodulators}

Immunomodulators are certain compounds that can increase the body's defense mechanism, both specifically and non-specifically, through cellular and humoral defense mechanisms. Immunomodulators function to repair impaired immune systems (immune restoration), suppressor normalizes abnormal immune reactions 


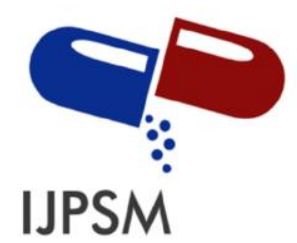

\section{Meilinda Mustika et al, Int. Journal of Pharmaceutical Sciences and Medicine (IJPSM), Vol.6 Issue. 3, March- 2021, pg. 14-20}

ISSN: 2519-9889

Impact Factor: 3.426

(immunosuppressants), increase the immune response (immunostimulants) [4]. Immunomodulators with natural ingredients can be obtained from native Indonesian herbal plants. Here are some explanations of some native Indonesian herbal plants used as immunomodulators, such as cinnamon, turmeric, meniran, and ginger.

\subsection{Cinnamon (Cinnamomum burmannii)}

Cinnamomum burmannii (Figure 1) is a type of herb from the Lauraceae family. Commonly known as cinnamon, it is found in Southeast Asia and Indonesia, used as a spice in cooking and traditional medicine [6]. Cinnamomum burmannii contains tannins and volatile oil up to 4\%: Cinnamaldehyde (60-75\%), benzaldehyde and cumin aldehyde; phenols (4-10\%) including eugenol, and methyl eugenol, pinene, phellandrene, cymene, and caryophyllene (hydrocarbons), eugenol acetate, cinnamyl acetate and benzyl benzoate (ester), linalool (alcohol). Cinnamon oil has antifungal, antiviral, bactericidal, and larvicidal, antiseptic, astringent pharmacological activity [7].

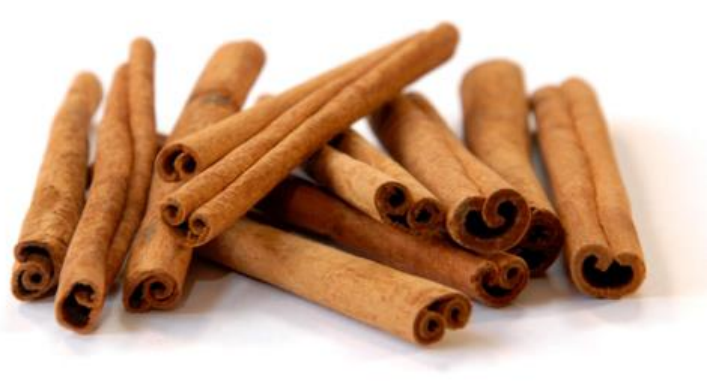

Figure 1: Cinnamomum burmannii

C. burmannii extract has the active compound cinnamaldehyde, which acts as an immunomodulator. Pratiwi $e t$ al. (2016) reported that $C$. burmannii extract increases granulocyte receptors and secretes IFN- $\gamma$, which activates macrophages to increase phagocytic activity. This activity was able to kill Salmonella enteritidis bacteria in thirty infected Wistar rats [4].

Astika et al. (2020) reported a study using 25 male Wistar rats randomly divided into five groups. The CN-G group was given standard feed, and the $\mathrm{CP}-\mathrm{G}$ group was given an everyday meal and $2.5 \mathrm{mg} / \mathrm{kg}$ of levamisole; the CBE-100, CBE-200, CBE-400 groups were given standard feed and $100 \mathrm{mg}$ of cinnamon extract, respectively. / $\mathrm{kg} \mathrm{BW}, 200 \mathrm{mg} / \mathrm{kg} \mathrm{BW}$, and $400 \mathrm{mg} / \mathrm{kg} \mathrm{BW}$. The treatment was given for seven days, and on the 8th day, the rats were injected intraperitoneally with $S$. aureus suspension. The results showed that the neutrophil and lymphocyte count was found to be significantly different in the CBE-100 group compared to the other groups. An increase in the value of neutrophils in leukocytes is also known as neutrophilic leukocytosis. This condition results from a normal immune response during bacterial or viral infections, injury, and inflammation. The above studies' results indicate that the ethanol extract of $C$. burmannii can be used as an immunomodulator that increases the immune response [8].

\subsection{Turmeric (Curcuma longa)}

Turmeric or Curcuma longa from the Zingiberaceae family is locally known as "kunyit or kunir" (Figure 2). Turmeric has a distinctive aroma and yellowish red color. The curcuminoids in turmeric, the most prominent being the unsaturated $\beta$-diketone curcumin (curcumin) which, together with desmethoxycurcumin (DMC) and bisdemethoxycurcumin (BDMC), make up 50-60\% of the curcuminoids present in the spice [9]. Its pharmacological activities include anti-inflammatory, antimicrobial, antiviral, antifungal, antioxidant, chemosensitizing, wound healing. Curcumin modulates T-cell proliferation and activation [10]. 


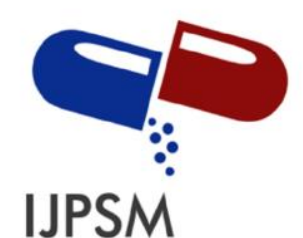

Meilinda Mustika et al, Int. Journal of Pharmaceutical Sciences and Medicine (IJPSM), Vol.6 Issue. 3, March- 2021, pg. 14-20

ISSN: 2519-9889

Impact Factor: 3.426

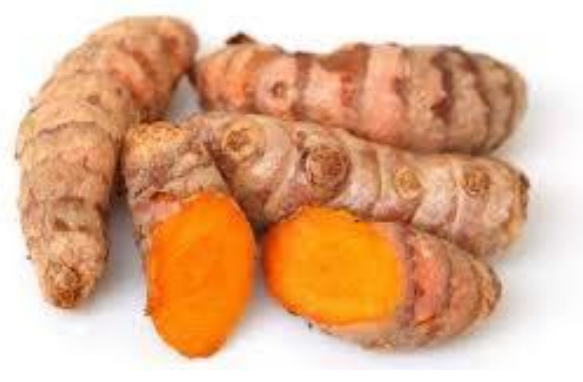

Figure 2. Curcuma longa

The immunomodulatory activity of the hot water extract fraction of Curcuma longa was investigated using peripheral blood mononuclear cells (PBMC). This study indicates that the polar fraction of the hot water extract of $C$. longa has a stimulating effect on the proliferation of PBMCs. Hot water extract of $C$. longa can be used as a supporting supplement for cancer patients undergoing chemotherapy. Patients with cancer also experience decreased immunity $[11,12]$.

\subsection{Meniran (Phyllanthus niruri)}

Phyllanthus niruri (meniran) (Figure 3) from the Phyllanthaceae family contains chemicals such as flavonoids, alkaloids, terpenoids, lignans, polyphenols, tannins, coumarins, and saponins.

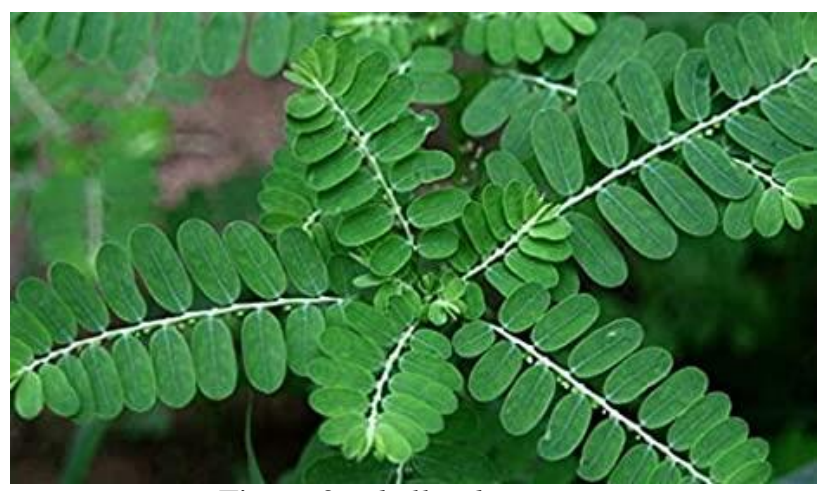

Figure 3. Phyllanthus niruri

In clinical studies, $P$. niruri has proven its ability to modulate and activate the immune system. $P$. niruri has medicinal effects on conditions such as dysentery, influenza, vaginitis, tumors, diabetes, diuretics, jaundice, kidney stones, dyspepsia, anti-hepatoxic, anti-hepatitis $\mathrm{B}$, and antihyperglycemic. $P$. niruri also has antiviral activity against the human immunodeficiency virus [13]. P. niruri extract showed significant anti-tumor activity. Flavonoids in $P$. niruri act as immunomodulators, especially as immunostimulators, because they can increase phagocytic activity and capacity as well as antibody titers [14].

\subsection{Ginger (Zingiber officinale)}

Zingiber officinale (Figure 4) is a type of medicinal plant from the Zingiberaceae family used as a cooking spice [15]. Zingiber officinale has secondary metabolic, including phenolic compounds such as gingerol, 


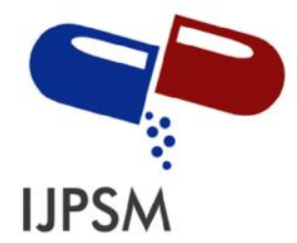

\section{Meilinda Mustika et al, Int. Journal of Pharmaceutical Sciences and Medicine (IJPSM), Vol.6 Issue. 3, March- 2021, pg. 14-20}

ISSN: 2519-9889

Impact Factor: 3.426

shogaol, and paradol, showing antioxidant, anti-inflammatory, and antiobesity properties. This plant also contains sesquiterpenes such as bisabolene, zingiberene, zingiberol, sesquiphellandrene, and curcumin $[15,16]$.

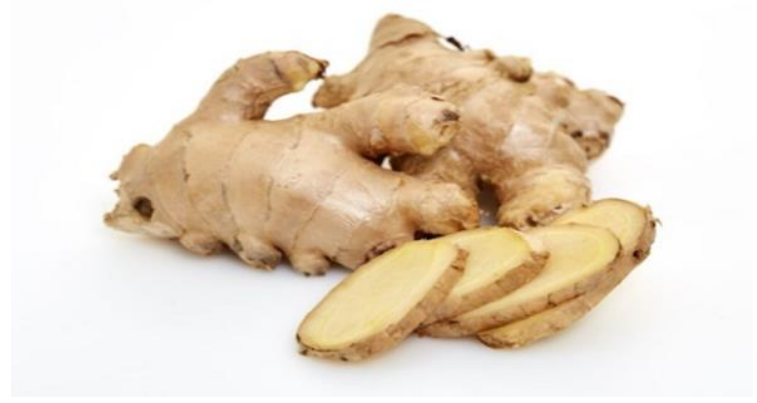

Figure 4: Zingiber officinale

Gingerol compounds are promising drug candidates for treating various diseases associated with inflammation, cancer, and viral infections. Traditionally. Zingiber officinale is formulated as a decoction and processed into ginger oil which is indicated to treat coughs, asthma, gout, anti-inflammatory, headaches and arthritis. Research of the chemical compound found in ginger is 6-gingerol. The bioactive compound from phenol found in the ginger rhizome, 6-gingerol, binds to the COVID 19 virus RNA protein to form hydrogen-bonding interactions. The energy binding affinities are -11.4082 and $-12.9523 \mathrm{KJ} / \mathrm{Mol}$. This bond energy reflects the good inhibitory activity against the COVID 19 virus [17].

\section{Conclusion}

The community has long used Indonesian native herbs, including Cinnamomum burmanii (cinnamon), Curcuma longa (turmeric), Phyllanthus niruri (meniran), Zingiber officinale (ginger), as health care, disease prevention. Its potential as an immunomodulator has been proven both preclinically and clinically through several studies. Immunomodulators are needed, especially in the current state of the COVID 19 pandemic.

\section{References}

[1]. Peraturan Menteri Kesehatan Republik Indonesia Nomor 6 Tahun 2016 Tentang Formularium Obat Herbal Asli Indonesia

[2]. Keputusan Menteri Kesehatan Republik Indonesia Nomor Hk.01.07/Menkes/187/2017 Tentang Formularium Ramuan Obat Tradisional Indonesia

[3]. Agustin T, Dachlan AS, Halim E. Penggunaan Imunostimulan Dalam Bidang Dermatovenereologi. Media Dermato Venereologica Indonesiana. 2019 Jul 26;46(2).

[4]. Pratiwi, T. S., Putri, A., \& Murwani, S. The effect of Cinnamomum burmannii extract as an immunomodulator on the increase of GR- 1 expressing IFN $\gamma$ and macrophage. 2015 (unpublished)

[5]. https://www.kemkes.go.id/article/view/20052100005/kemenkes-sarankan-masyarakat-manfaatkan-obattradisional.html, accessed Jan 25, 2021

[6]. Tan MX, Gan DH, Wei LX, Pan YM, Tang SQ, Wang HS. Isolation and characterization of pigment from Cinnamomum burmannii'peel. Food research international. 2011 Aug 1;44(7):2289-94.

[7]. Barnes J, Anderson LA, Phillipson JD. Herbal medicines. Third Edition. London \& Chicago. Pharmaceutical Press. 2007.

[8]. Utomo AW, Retnoningrum D, Gumay AR. The Immunomodulatory Effect of Cinnamon (Cinnamomum Burmanii) Bark Extract On the C-Reactive Protein (CRP) Level, Leukocyte Count and Leukocyte Type Count of Wistar Rats Exposed to Staphylococcus aureus. Sains Medika: Jurnal Kedokteran dan Kesehatan. 2020 Jul 5;11(1):1-6. 


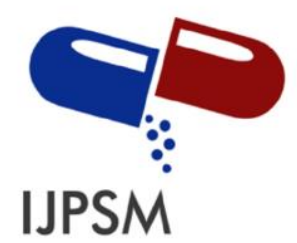

\section{Meilinda Mustika et al, Int. Journal of Pharmaceutical Sciences and Medicine (IJPSM), Vol.6 Issue. 3, March- 2021, pg. 14-20}

[9]. R Cundell D, Wilkinson F. Curcumin: Powerful immunomodulator from turmeric. Current Immunology Reviews. 2014 Nov 1;10(2):122-32.

[10]. Mehrotra S, Agnihotri G, Singh S, Jamal F. Immunomodulatory potential of Curcuma longa: a review. South Asian J. Exp. Biol. 2013;3(6):299-307.

[11]. Yue GG, Chan BC, Hon PM, Kennelly EJ, Yeung SK, Cassileth BR, Fung KP, Leung PC, Lau CB. Immunostimulatory activities of polysaccharide extract isolated from Curcuma longa. International journal of biological macromolecules. 2010 Oct 1;47(3):342-7.

[12]. Yue GG, Chan BC, Hon PM, Lee MY, Fung KP, Leung PC, Lau CB. Evaluation of in vitro anti-proliferative and immunomodulatory activities of compounds isolated from Curcuma longa. Food and chemical toxicology. 2010 Aug 1;48(8-9):2011-20.

[13]. Tjandrawinata RR, Susanto LW, Nofiarny D. The use of Phyllanthus niruri L. as an immunomodulator for the treatment of infectious diseases in clinical settings. Asian Pac. J. Trop. Dis. 2017;7(3):132-40.

[14]. Zalizar L. Flavonoids of Phyllanthus niruri as immunomodulators a prospect to animal disease control. ARPN Journal of Science and Technology. 2013;3(5):529-32.

[15]. Ashokkumar K, Murugan M, Dhanya MK, Sathyan T, Raj S, Mathews N. Traditional Uses, Phytochemistry, and Pharmacological Properties of Zingiber officinale Essential Oil and Extracts. In Ethnopharmacological Investigation of Indian Spices 2020 (pp. 62-84). IGI Global.

[16]. Al-Nahain A, Jahan R, Rahmatullah M. Zingiber officinale: A potential plant against rheumatoid arthritis. Arthritis. 2014;2014.

[17]. Rathinavel T, Palanisamy M, Palanisamy S, Subramanian A, Thangaswamy S. Phytochemical 6-Gingerol-A promising Drug of choice for COVID-19. Int J Adv Sci Eng. 2020 May 29;6(4):1482-9.

\section{A Brief Author Biography}

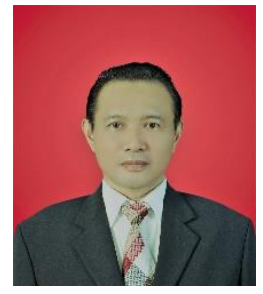

Prof. Dr. Harrizul Rivai, M.S., was born in Payakumbuh, West Sumatra, on 4 September 1953. His father is Rivai Said, and his mother is Saridahanum Syofyan. The Author obtained a Bachelor of Pharmacy from the Department of Pharmacy, Faculty of Mathematics and Natural Sciences, Padjajaran University, Bandung (1976), a Master of Science degree from the Bandung Institute of Technology (1984), and a Doctorate from the Department of Chemistry, Faculty of Mathematics and Natural Sciences, Andalas University, Padang (2011). Now the Author is a Professor and Researcher at the Faculty of Pharmacy, Andalas University, Padang. The Author also serves as Deputy Chair of Academic Affairs at the YPTIK Padang College of Pharmacy (STIFARM). The Author wrote the book "Principles of Chemical Examination" (Publisher UI-Press, 1995), translated the book "Pharmaceutical Statistics" (EGC Medical Book Publishers, 2010), and wrote "Chapter 4" in the book "Recent Research Advances in Biology Vol. 4 "(International Book Publisher, India, and United Kingdom, 2020). The Author has also written articles in various international journals in various science fields, such as chemistry, biology, and pharmacy. 